\title{
Corporate Vulnerabilities in India and Banks' Loan Performance
}


Corporate Vulnerabilities in India and Banks' Loan Performance

\author{
Peter Lindner and Sung Eun Jung
}




\title{
IMF Working Paper
}

Asia and Pacific Department

\section{Corporate Vulnerabilities in India and Banks' Loan Performance Prepared by Peter Lindner and Sung Eun Jung ${ }^{1}$}

Authorized for distribution by Paul Cashin

December 2014

\section{This Working Paper should not be reported as representing the views of the IMF.}

The views expressed in this Working Paper are those of the author(s) and do not necessarily represent those of the IMF or IMF policy. Working Papers describe research in progress by the author(s) and are published to elicit comments and to further debate.

\begin{abstract}
The financial performance of India's corporate sector has been under pressure since the Global Financial Crisis. Balance-sheet data on a large cross-section of Indian non-financial corporates show that the growth in their leverage over the last 15 years has been associated with a notable increase in the vulnerabilities of firms carrying high interest payment burdens. Gauged by the debt carried by the most vulnerable component of firms, the Indian corporate sector's vulnerability to severe systemic shocks has increased to levels not seen since 2001. Progress on the macroeconomic front, together with improved credit appraisals and stricter impairment standards on the bank side, will be critical to help India's banks resume their role as economic growth drivers.
\end{abstract}

JEL Classification Numbers: D22, G01, G30, G32, F30.

Keywords: Financial crisis, firm resilience, bank-corporate dependencies, leverage, corporate performance, India.

Authors’ E-Mail Addresses: plindner@imf.org ; sjung@imf.org

\footnotetext{
${ }^{1}$ We are grateful to Rahul Anand, Paul Cashin, Luc Everaert, Janak Raj, Thomas Richardson, Volodymyr Tulin, and our colleagues in the Asia and Pacific Department and Monetary and Capital Markets Department for helpful comments and discussions. We also benefited from the feedback received from seminar participants at the Reserve Bank of India (November, 2013), and the Indian Ministry of Finance (November, 2013).
} 


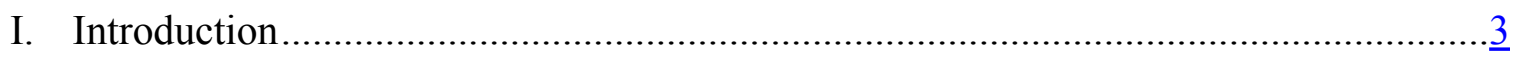

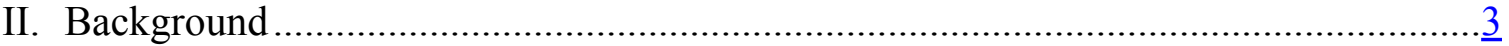

A. Economic Performance and Corporate Risks ..................................................

B. Corporate Vulnerabilities: Corporates' Risk Indicators over Time ......................... 5

C. Corporate Vulnerabilities: Stress-Testing Corporate Balance Sheets ...................... $\underline{6}$

D. India's Banks, Corporate Vulnerabilities, and the Impact of Basel III...................

III. Conclusions and Policy Implications ..........................................................

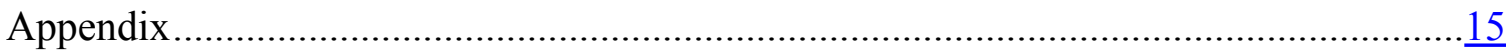

Figures

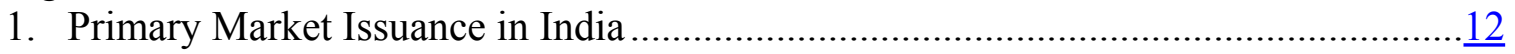

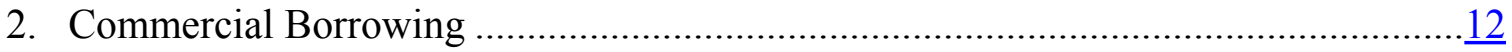

3. Leverage Ratio for Indian Non-Financial Corporates .......................................12

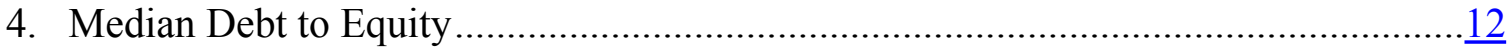

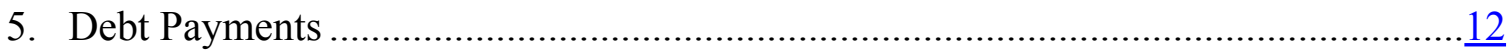

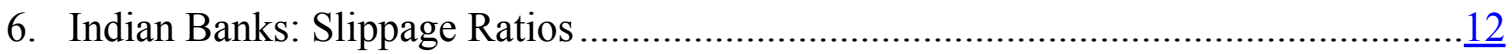

7. Expected Default Frequencies of Indian Corporates ….......................................13

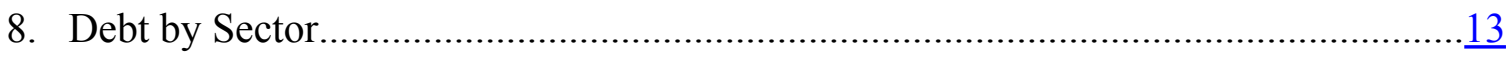

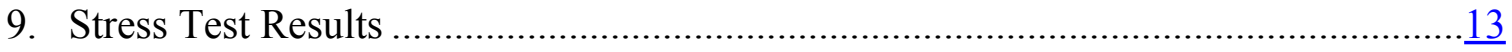

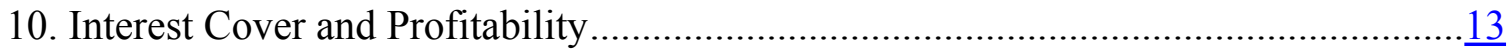

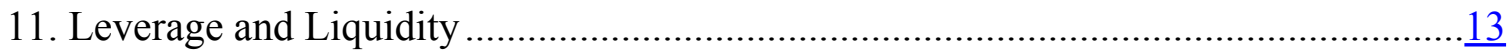

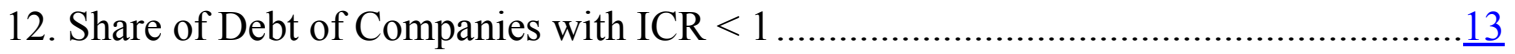

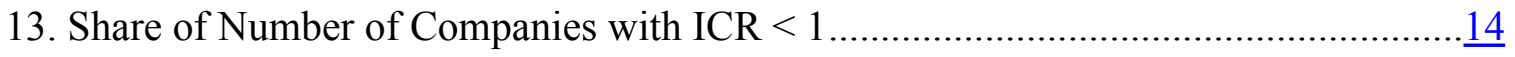

14. Gross NPAs, Restructured Advances, and Slippages ......................................... 14

15. Loan Impairments vs. Tier 1 Ratio, March 2013 ......................................................

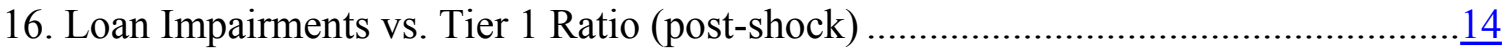

Tables

1. Government's Share of PSB Recapitalization ......................................................

2. Indian Banks' Recapitalization Costs Under Basel III: Additional Capital Requirements as Percent of 2018 GDP .......................................................

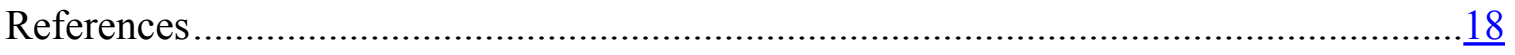




\section{INTRODUCTION}

This paper focuses on the changes in financial vulnerabilities of India's non-financial corporate sector ('corporates') over the past 25 years, and the implications for Indian banks' loan performance. Four indicators of corporates' financial health are tracked through time, and are subjected to various economic shocks. Low levels of one of the indicators, leverage, has been shown be associated with more resilient firms at the onset of a crisis, and with the ability of firms to recover more forcefully from a crisis (Medina, 2012). Others have found evidence that major corporate financial vulnerabilities can constitute an indicator of future financial crises (Jones and Karasulu, 2006). With corporate leverage in emerging markets moving to the forefront of concerns by analysts and policymakers, obtaining a proper picture of the changing nature of corporate vulnerabilities in a large country such as India is very important in and of itself. This issue is particularly important because of the recent growth slowdown in India, and as an input to help answer the question as to how best to revive Indian economic growth.

The second section of this paper relates Indian corporate vulnerabilities to the increasing levels of non-performing and restructured loans in the banking system. We find that corporate vulnerabilities can explain a large part of bank non-performing advances (NPAs). Growing weakness in the corporate sector, which would likely exacerbate NPAs, could thereby weaken India's banks, most notably at about the same time as they have to increase capital levels under Basel III, potentially reducing their ability to provide bank credit.

\section{BACKGROUND}

\section{A. Economic Performance and Corporate Risks}

The eight years before the global financial crisis (GFC) in 2008 were not only a period of notable economic expansion for India, but also of significant strengthening of India's corporate balance sheets. Between March 2001 and March 2008, the Bombay Stock Exchange (BSE) Index rose almost four-fold, while the value of BSE-listed equities increased nine-fold; primary market equity issuance became a major means of financing for Indian corporations. Together with the increase in profitability, leverage declined, especially in the last few years before the crisis. Although domestic bank credit and external debt grew rapidly before the GFC, the market-to-book ratio of Indian corporates more than tripled between 2001 and 2006, and the interest cover ratio (ICR) more than doubled (Figure 1). Over the same period, corporate India's return on equity almost doubled. ${ }^{2}$

\footnotetext{
${ }^{2}$ Oura (2008) provides an in-depth discussion of Indian corporates' financial structure before the GFC.
} 
Starting in 2012, India's economic growth decelerated sharply, accompanied by an even more significant decline in investment (Anand and Tulin, 2014). Some of India's economic resilience was supported by increases in government spending initiated before the crisis; another part was driven by a push towards infrastructure spending, which began around 2004, and was supported by credit growth, mainly through public sector banks (PSBs). During that period, corporate borrowing as a share of GDP reached new heights year after year.

However, during the current slowdown, a number of indicators of corporate financial health began to deteriorate. Domestic credit to corporates continued to rise during and after the GFC (Figure 2), driven notably by public banks' increased supply of credit, notably for infrastructure projects. In addition, foreign currency debt in the form of external commercial borrowings (ECBs) has risen by 71 percent between March 2010 and March 2013. Corporate leverage rose as the equity market saw relatively few issuances after the GFC (Figure 3), and stock price performance was fairly lackluster. The (equity capital-weighted) mean ratio of debt to equity for Indian nonfinancial companies increased from 40 percent in 2001 to 83 percent in 2012. Indian corporates are now among the most leveraged, when compared with their emerging market peers (Figure 4). Furthermore, overall leverage measures disguise substantial differences across sectors - specifically manufacturing and construction (both sectors with heavy exposure to infrastructure and power).

External corporate funding creates potential feedback loops between corporate vulnerabilities and external shocks. Indian corporates rely on foreign sources for more than one-fifth of their debt financing, including ECBs, trade credits, and bonds. Not only has foreign financing grown, but ECBs have also become concentrated, with about a sixth of approved foreign loans going to only 14 large conglomerates (Credit Suisse, 2013). BIS data show that nearly two-thirds of India's liabilities to BIS reporting banks are borne by nonbank companies, with much of that debt being short-term (Figure 5). In addition, debt service payments over the upcoming two years are forecast to come in at higher levels than during the GFC, and their maturity profile has shortened. About 35 percent of ECBs are estimated to be hedged with financial instruments, with the scope of 'natural', business-related hedges difficult to estimate (Financial Express, 2012).

The deterioration in corporate balance sheets and profitability is being reflected in marketbased indicators of credit risk, and increased rates of loans entering non-performing status ('slippage ratio', see Figure 6). Default probabilities as estimated by Moody's KMV have also begun to rise (Figure 7). ${ }^{3}$ Notably, even though the KMV default probability for the median firm remains below the levels reached during the GFC, the default probability for the

\footnotetext{
${ }^{3}$ Moody's KMV is a model of default risk based on the Black-Scholes-Merton model, combining balance sheet and equity market data (Moody's, 2004).
} 
90th percentile exceeds now the levels witnessed during the GFC, pointing to significant stress at the tail of the corporate default distribution. Corporate India's worsening performance is reflected in the share of loans that enter non-performing status (slippages), which is at its highest level since 2003.

\section{B. Corporate Vulnerabilities: Corporates' Risk Indicators over Time}

We gauge India's corporate health based on four frequently-used indicators: interest-cover ratio (ICR), ${ }^{4}$ profitability, ${ }^{5}$ liquidity, and leverage. ICR and profitability are indicators of a firm's performance over a shorter period like a quarter or a year, assessing the degree to which current activities allow the funding of interest expenses, or whether a firm's combined operating and financial activities are self-funding, respectively. Both measures are essentially snapshots, taken at a particular point in time. An ICR below one, or a lack of profitability, does not indicate that insolvency is imminent. Firms can have investments that are liquid or can be easily used as collateral for borrowing, open credit lines, or other sources of funding which could carry them through. Nevertheless, low levels of ICRs are found to be a good indicator of systemic vulnerabilities. For example, stress testing of the ICRs of Korean corporations prior to the Asian crisis of the late 1990s would have provided a very good indication of the degree of financial vulnerabilities present in the country (Jones and Karasulu, 2006).

Based on these four indicators (ICR, profitability, liquidity and leverage), derived from the Center for Monitoring Indian Companies (CMIE) Prowess database (covering the period 1990/91-2012/13), we find that corporate vulnerabilities of Indian non-financial corporations are at their highest levels since the early 2000s (Appendix Table A1). ${ }^{6}$ As of March 2013, the percentage of debt owed by loss-making firms exceeded 26 percent. Indian companies whose total debt exceeds five times equity account for almost 30 percent of the borrowings of Indian corporates. Furthermore, a composite measure of corporate vulnerabilities indicates that the financial health of Indian corporates is at its weakest since March 2003. ${ }^{7}$ Moreover, the share of corporate borrowing by the sectors that experienced recent financial strains - such as infrastructure, mining, and commercial construction - has increased since 2008. Lending to the power sector experienced a sharp increase in the early 2000s. As well,

\footnotetext{
${ }^{4}$ The ICR is usually defined as EBIT or EBITDA (Earnings before Interest, Taxes, Depreciation and Amortization) divided by interest expenses. This paper uses EBITDA.

${ }^{5}$ For the purposes of this paper, profitability is defined on a relative basis as net profit divided by total sales. The findings here mirror those found in Lindner (2014).

${ }^{6}$ The sample covers about 2,000 firms as of end-March 2013, which are followed backward through time. The initial sample size is constrained by the availability of Prowess data at the time of the investigation.

${ }^{7}$ It should be noted that in the late 1990s and early 2000s, leverage looked significantly worse than in FY 2012/13.
} 
the share of lending to commercial construction increased from 2.8 percent in 2004 to 7.2 percent of the debt in our sample in 2013 (Figure 8).

\section{Corporate Vulnerabilities: Stress-Testing Corporate Balance Sheets}

Properly implemented stress tests of corporate balance sheets can expose vulnerabilities to financial shocks. Core financial metrics of corporates can reveal their ability to weather financial stresses, which are often caused by macroeconomic factors, as well as provide an indication of firms' ability to adapt to changes in their business environment. For example, changes in exchange rates or interest rates can adversely affect a firm's equity and also its debt servicing capacity. Anticipating potential problems, lenders may choose not to roll over debt, or not to provide new credit to companies that may become distressed. The 1997-98 Korean crisis, driven by highly indebted corporates, provides a prime example of these effects (Jones and Karasulu, 2006) as banks curtailed lending to troubled firms. Corporates' inability to service their debts will lead to higher NPAs, leading to banking sector stress. Reduced corporate investment, as well as inadequate credit provisioning to the broader economy, can engender subpar economic performance for prolonged periods of time.

This section focuses on the impact that adverse shocks to macro-financial conditions can have on corporate sector vulnerabilities, as measured by the balance sheet-based indicators described above. Specifically, four financial variables-domestic and foreign interest rates, profitability and exchange rates-were shocked individually and jointly, and the share of total in-sample debt owed by firms exhibiting an ICR below 1 was calculated for each of these five cases. The types and magnitudes of the four shocks are calibrated to financial market developments observed during the summer of 2013, and to the change in profitability experienced in 2009. The shocks include: an increase in domestic interest rates by 250 basis points (bps); an increase in foreign interest rates by 400 bps; a decrease in operating profit by 25 percent; and a 29 percent depreciation of the rupee. Once again, the CMIE Prowess database of Indian corporates provides the data analyzed. A shock's impact on each variable is evaluated by increasing (or decreasing) its value at end-FY 2012/13, and then calculating every firms balance sheet and its profit and loss given that change.

Indian corporates' balance sheet vulnerabilities to financial shocks have increased since the GFC, and are at their highest level since March 2002 (see Appendix Table A2). Comparing the baseline share of debt owed by firms with ICR below one from 1990/91 to 2012/13, the debt owed by firms with ICR below one in 2013 is much higher than it was in March 2008, before the GFC hit India. The current baseline also exceeds its 2009 values markedly (Figure 9). The impact of each of the four shocks is defined as the share of debt carried by the firms with an ICR below one post-shock. The impact of individual shocks, as well as the combined shock, is positively correlated with the baseline values. 
However, vulnerabilities to exchange rate and foreign interest shocks are not large relative to each year's baseline. ${ }^{8}$ This finding is at odds with the often-expressed concern that unhedged FX liabilities of Indian corporates could adversely affect the Indian economy. In part this could be due to the fact that our analysis also takes into account FX-denominated assets, which can to some extent counteract the adverse impact of these shocks on FX-denominated liabilities.

Moreover, the 2012/13 stress tests indicate significantly higher vulnerabilities than the $2007 / 08$ or 2008/09 stress tests. ${ }^{7}$ Also, over the past year, the vulnerabilities to all four shocks have increased - in particular to the domestic interest rate and the profitability shocks. This indicates that the protracted low-growth environment, coupled with higher leverage, has made India's corporates much more vulnerable. In particular, under the combined shock scenario - all four variables being shocked simultaneously - the share of debt affected increases from 11.1 percent in 2007/08 to 36.4 percent in 2012/13. The combined shock's impact in 2013 is the second-highest on record, only 2.2 percentage points below its 1999 value.

A comparison of the 2012/13 stress tests with the 2007/08 or 2008/09 stress test results also indicates the shift in the universe of vulnerable firms from larger firms to smaller ones, confirming a development noted by a number of observers. When comparing the share of the debt affected with the share of the number of firms affected by the shocks in 2001, 2008, and 2013, the baseline and the post-shock shares of debt are of similar size to 2001, reaching a trough in 2008. However, the share of affected firms increases monotonically between the three periods, confirming a shift of vulnerabilities from larger to smaller firms.

Over time, vulnerabilities as measured by the ICR over each year's baseline have increased significantly for the shocks to domestic interest rates and to operating profits, but less so for the combined shock (Figure 9 and Appendix Table A2). In 1999/2000, a 25 percent reduction in operating profits would have resulted in an increase in the share of debt owed by firms with an ICR below 1 by about 6 percentage points over baseline; in 2012/13, the increase in the share of debt owed by the more vulnerable component of firms would have amounted to about 9 percentage points over baseline. Similarly, the domestic interest rate shock in $1999 / 2000$ would have led to an increase in the share of debt owed by firms with an ICR under one of close to 4 percentage points over baseline; in 2012/13, that increase was 5 percentage points. For the combined shock, the increase in the share of vulnerable debt over baseline in 2012/13 is close to 20 percentage points; while in 1999/2000, that number was only 12 percentage points.

\footnotetext{
${ }^{8}$ The exchange rate shock applies to the INR/\$ rate; on the interest rate side, all foreign rates and spreads are shocked, based on data from Barclays' Emerging Markets USD Corporate Index.
} 


\section{India's Banks, Corporate Vulnerabilities, and the Impact of Basel III}

The worsening financials of India's corporates have led to notable increases in banks' NPAs and of restructured advances on their books. In the aftermath of the GFC, restructured advances were provided regulatory forbearance by the RBI, which provided corporations and banks a temporary reprieve from the repercussions of the crisis. Not being placed into the NPA-category, restructured advances originally needed to be provisioned against at a rate of only two percent. After a decline in 2009/10, the share of restructured advances has increased every year. Growth of restructured loans have been especially pronounced at the public sector banks (PSBs) (Figure 14), having raised concerns among many analysts about the "ever-greening" of loans that should have been declared non-performing and provisioned against at a higher rate. Concerned with the underlying asset quality of restructured loans, a number of observers have included part or all of the restructured advances into NPAs to arrive at a total measure of stressed loans in the banking system (Morgan Stanley, 2012; Standard \& Poor's, 2014).

Empirical analysis (Appendix Table A3) confirms the predictive power of some of the vulnerability indicators explored earlier in explaining future additions to NPAs, of which ICR, profitability and short-term interest rate appear to have the highest individual predictive power. ${ }^{9}$ To formally establish the predictive power of various financial indicators, we separately regress the gross slippage ratio ${ }^{10}$ in India's banking system on 15 different explanatory variables, as well as its own lagged values, to determine the marginal forecasting power of each of the variables. The explanatory variables include the share of debt accounted for by firms that are below/above our four indicators' thresholds, plus 11 macro-variables, including real and nominal interest rates. ${ }^{11}$ The highest $\mathrm{R}$-squared is provided by the regression including the nominal short rate, at 85.8 percent. The profitability indicator comes in at 85.1 percent, and the ICR at 82.9 percent. Real short and long rates result in R-squared values of 83.2 and 83.1 percent, respectively. Accordingly, it appears that profitability pressures have adversely affected corporate India's ability to make good on its financial obligations.

\footnotetext{
${ }^{9}$ Table A2 in the Appendix shows corporate India's vulnerabilities at levels similar to the early 2000s. On the other hand, NPAs were significantly higher during that period than today. This discrepancy can be partially explained by today's higher share of borrowings coming from capital markets, increased FX-denominated loans, and the presence of large amounts of restructured advances.

${ }^{10}$ The slippage ratio is the ratio of newly-added NPAs in year $t$ divided by the outstanding advances at the end of year $t-1$. We choose gross slippages since out of the variables available - gross NPAs, net NPAs, gross and net slippages - they are most directly driven by corporate health, and less by banks' ability and willingness to take losses.

${ }^{11}$ The list of variables and details on the results can be found in Appendix Table A3.
} 
If Indian corporates become severely distressed, India's banks would be likely to require significant new capital injections over the next few years. In addition, capital would also need to be raised to meet Basel III capital requirements. Stress-testing banks' capital position with regards to a sudden deterioration in loan quality indicates greater weaknesses amongst the PSBs compared to private banks, ${ }^{12}$ while a dynamic simulation approach found notably greater needs for capital infusions by PSBs.

The stress tests also indicate that PSBs are particularly vulnerable to the transition of a significant share of restructured loans into NPAs. Each bank's balance sheet was stressed individually, based on 45 percent of restructured advances moving to NPAs, and those NPAs being provisioned against loss at a minimum 60 percent. ${ }^{13}$ All banks are compared with regard to their Tier 1 capital ratio and their ratio of impaired loans after provisions. As of March 2013, the average Tier 1 ratio of private banks is more than 3 percentage points higher than the average Tier 1 ratio of public sector banks, with private banks impaired-loans-toprovisions ratio almost 1.4 percent lower (Figure 15). However, in the stress scenario, the average Tier 1 ratio decreased by about 1.7 percent for the PSBs, and by less than 0.4 percent for the private sector banks. Impaired loans after provisions increased by an average of almost 1.4 percent for the PSBs, and by less than 0.3 percent for private banks (Figure 16).

Employing more severe stress assumptions indicates the potentially significantly higher recapitalization costs for the government (Table 1). Based on a doubling of the NPAs and restructured loans across public sectors banks, together with three alternative provisioning ratios (restructured loans provisioned at 50 percent (Scenario 1), both restructured loans and the existing NPAs at 75 percent (Scenario 2), and both at 100 percent (Scenario 3)), under a 7 percent Tier 1 target capital ratio for all PSBs, the government's share of the recapitalization cost could amount to about 5 percent of 2012/13 GDP under Scenario 3.

Table 1. Government's Share of PSB Recapitalization

(share of 2012-13 GDP; in percent):

Scenario 1 Scenario 2 Scenario 3

\begin{tabular}{llll} 
Public Sector Share & 2.1 & 3.5 & 5.0 \\
Total & 3.3 & 5.5 & 7.9 \\
\hline
\end{tabular}

Source: Bankscope and IMF staff calculations.

\footnotetext{
${ }^{12}$ United Bank of India's (BoI's) recent travails provide an example. Throughout 2013, BoI's NPAs increased rapidly, with the Bank getting close to breaching limits on minimum capital ratios. In February 2013 the chairwoman resigned, while serious lapses in corporate governance were alleged, besides other charges, and the Reserve Bank of India (RBI) ordered a forensic accounting investigation (Economic Times (2013)).

${ }^{13}$ Sixty percent if the bank used a lower provisioning ratio in 2012/13, and its 2012/13 ratio otherwise.
} 
The additional bank capital that will need to be raised for the PSB's based on Basel III's capital requirements will likely be moderate, although not negligible (Table 2). The capital needs of public sector banks will differ depending on credit growth, and on the amount of capital that banks will choose to hold above the regulatory minimum of 7 percent in March 2018. Under each of the alternative values of the capital ratio cushion above the regulatory minimum - 0,1 , and 2 percent — and using return on assets (ROA) or return on equity (ROE) as the profit driver, the capital injection cost for the central government would not exceed 2 percent of FY 2017/18 GDP. ${ }^{14,15}$

Table 2. Indian Banks' Recapitalization Costs under Basel III: Additional Capital Requirements as Percent of 2018 GDP 1/ 2/

\begin{tabular}{|c|c|c|c|c|c|c|c|}
\hline \multicolumn{4}{|c|}{ ROA-Based Simulations } & \multicolumn{4}{|c|}{ ROE-Based Simulations } \\
\hline \multirow{3}{*}{$\begin{array}{c}\text { Total Capital in } \\
2018(\%) 3 /\end{array}$} & \multicolumn{3}{|c|}{ Credit Growth (Multiple of GDP Growth) } & \multirow{3}{*}{$\begin{array}{l}\text { Total Capital in } \\
2018(\%) 3 /\end{array}$} & \multicolumn{3}{|c|}{ Credit Growth (Multiple of GDP Growth) } \\
\hline & Slow ( GDP) & Base $\left(\sim 1.5^{*} \mathrm{GDP}\right)$ & Fast $(\sim 2 * G D P)$ & & Slow ( GDP) & Base $\left(\sim 1.5^{*} \mathrm{GDP}\right)$ & Fast $(\sim 2 * G D P)$ \\
\hline & \multicolumn{3}{|c|}{ Government's Share } & & \multicolumn{3}{|c|}{ Government's Share } \\
\hline $7(0)$ & 0.00 & 0.11 & 0.62 & $7(0)$ & 0.02 & 0.31 & 1.07 \\
\hline $8(1)$ & 0.06 & 0.36 & 1.01 & $8(1)$ & 0.14 & 0.62 & 1.47 \\
\hline $9(2)$ & 0.22 & 0.66 & 1.41 & $9(2)$ & 0.35 & 0.92 & 1.87 \\
\hline \multicolumn{5}{|c|}{ Total for Public Sector Banks } & \multicolumn{3}{|c|}{ Total for Public Sector Banks } \\
\hline $7(0)$ & 0.00 & 0.17 & 0.96 & $7(0)$ & 0.03 & 0.49 & 1.67 \\
\hline $8(1)$ & 0.09 & 0.55 & 1.58 & $8(1)$ & 0.21 & 0.96 & 2.29 \\
\hline $9(2)$ & 0.34 & 1.02 & 2.20 & $9(2)$ & 0.54 & 1.44 & 2.91 \\
\hline \multicolumn{5}{|c|}{ Total for Private Banks } & \multicolumn{3}{|c|}{ Total for Private Banks } \\
\hline $7(0)$ & 0.00 & 0.00 & 0.04 & $7(0)$ & 0.00 & 0.00 & 0.13 \\
\hline $8(1)$ & 0.00 & 0.01 & 0.16 & $8(1)$ & 0.00 & 0.02 & 0.31 \\
\hline $9(2)$ & 0.01 & 0.06 & 0.35 & 9 (2) & 0.01 & 0.09 & 0.52 \\
\hline
\end{tabular}

Sources: RBI; BankScope; IMF staff calculations.

1/ Simulations based on 2012 data (except ROA and ROE, where 2011 \& 2012 averages where used).

2/ A 15 percent transition rate from restructured loans to NPAs is assumed.

3/ Numbers equal Equity Tier 1 ratio plus Capital Conversation Buffer plus additional cushion of 0, 1, or 2 percentage points.

\section{CONCLUSIONS AND POLICY IMPlications}

The financial stability metrics of India's corporates, and their resilience to macro-financial shocks, have deteriorated to levels last observed in 2002/03. Although the average or median values of financial metrics such as leverage or ICR are not alarming in an historical context, the share of debt owed by firms in the tails of the indicators' distributions-beyond specific threshold values-has increased significantly. This implies greater risk for India's corporates, its banks, and the broader economy. Growth-enhancing measures will help mitigate these risks and bolster bank balance sheets, particularly among public sector banks. The results of this paper, in conjunction with work done by others (Tokuoka, 2012; Anand and Tulin, 2014), suggest that structural reforms, improvements to the business climate, and reduced

\footnotetext{
${ }^{14}$ The simulations are based on stock values at the end of March 2013, and returns and other flow variables averaged across fiscal years 2012 and 2013.

${ }^{15}$ See also Box 5 in IMF (2014). The scenarios that are deemed more likely are highlighted in Table 2.
} 
uncertainty can be helpful in this regard. As well, measures to address bank asset quality deterioration, including through enhancing the legal and institutional insolvency framework and functioning of distressed asset markets, would help improve the economy's overall financial health as well as support broad-based growth revival. The recently-enacted Companies' Law and the accelerated permission process for large projects represent steps in the right direction.

Although public sector banks' capital needs to withstand a severe NPA shock would be considerable, they appear manageable for the government. Moreover, additional capital needs to meet Basel III requirements also appear to be manageable. However, the ultimate goal should be to have banks operating on purely commercial principles and able to finance themselves in the capital markets. The Reserve Bank of India's (RBI) efforts to strengthen credit culture in the banking sector, including through less reliance of restructured loans, is very much welcome. 


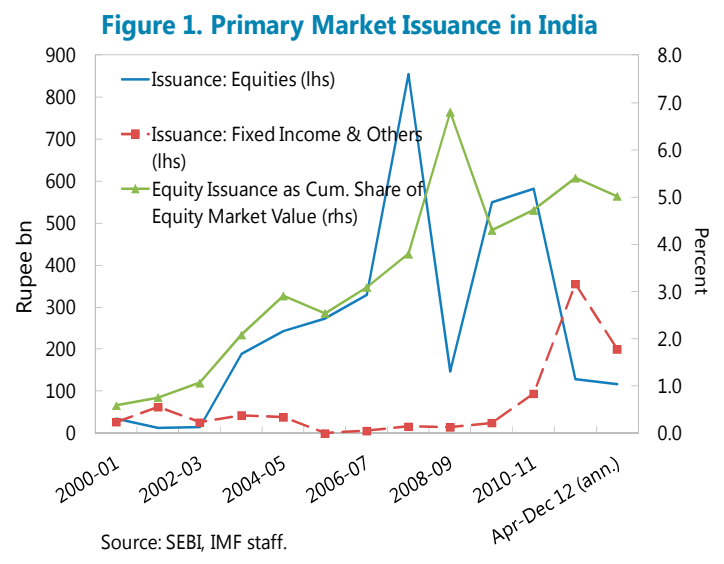

Figure 3. Leverage Ratio for Indian Non-Financial Corporates

(Capital-weighted mean ratio of debt-to-equity)

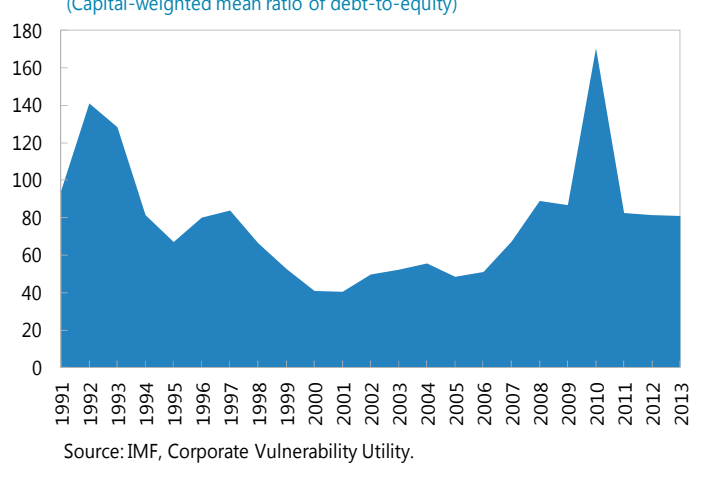

Figure 5. Debt Payments

(In billions of US\$)

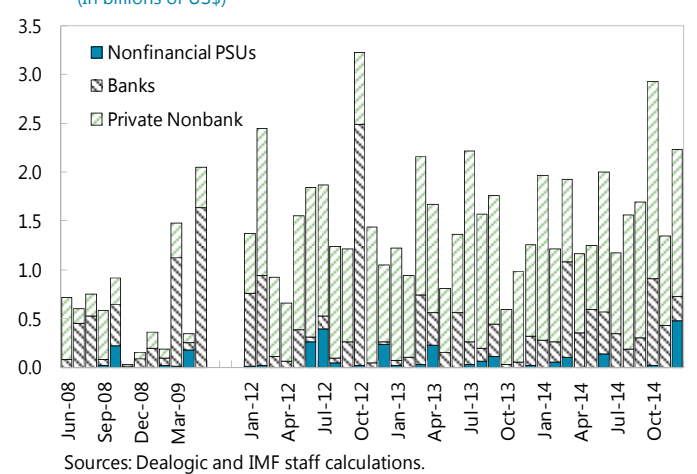

Figure 2. Commercial Borrowing

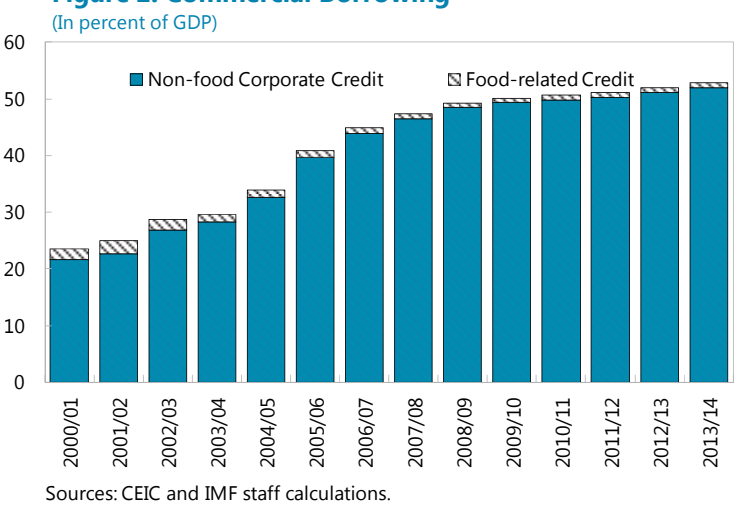

Figure 4. Corporates: Median Debt to Equity (In percent)

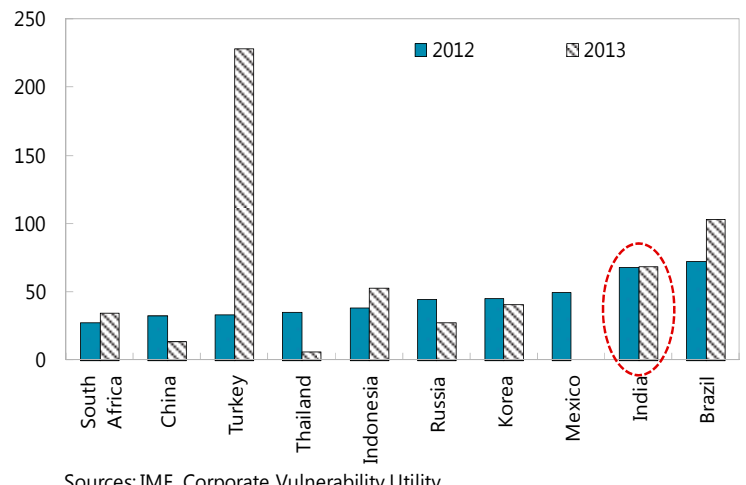

Sources: IMF, Corporate Vulnerability Utility.

Figure 6. Indian Banks: Slippage Ratios

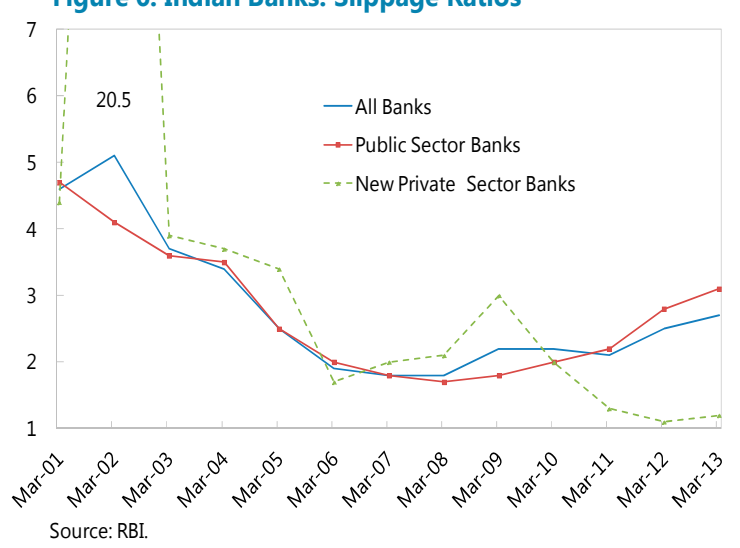




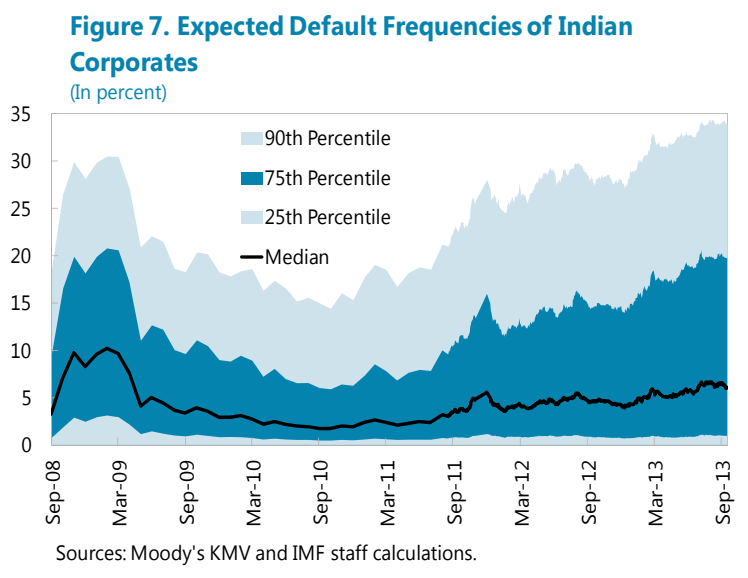

Figure 9. Stress Test Results

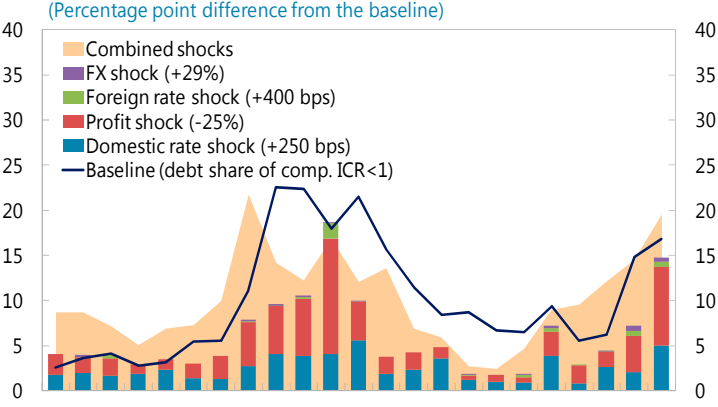

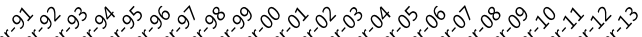

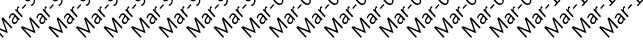

Sources: CMIE Prowess database; and IMF staff calculations.

Figure 11. Leverage and Liquidity

(In percent of all firms in sample)

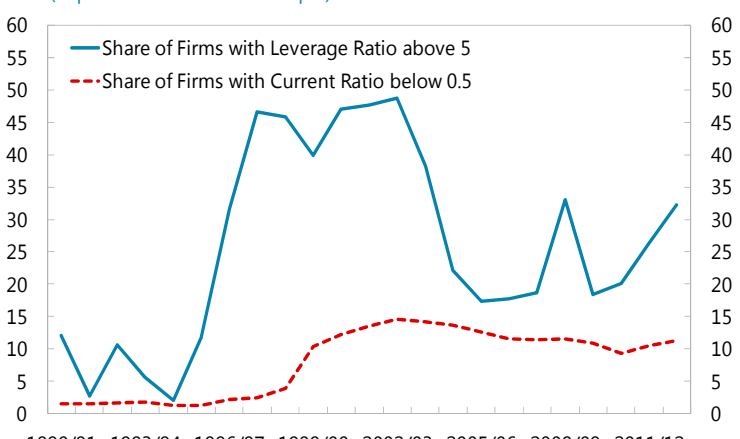

1990/91 1993/94 1996/97 1999/00 2002/03 2005/06 2008/09 2011/12 Source: CMIE Prowess; IMF staff calculations.
Figure 8. Debt by Sector

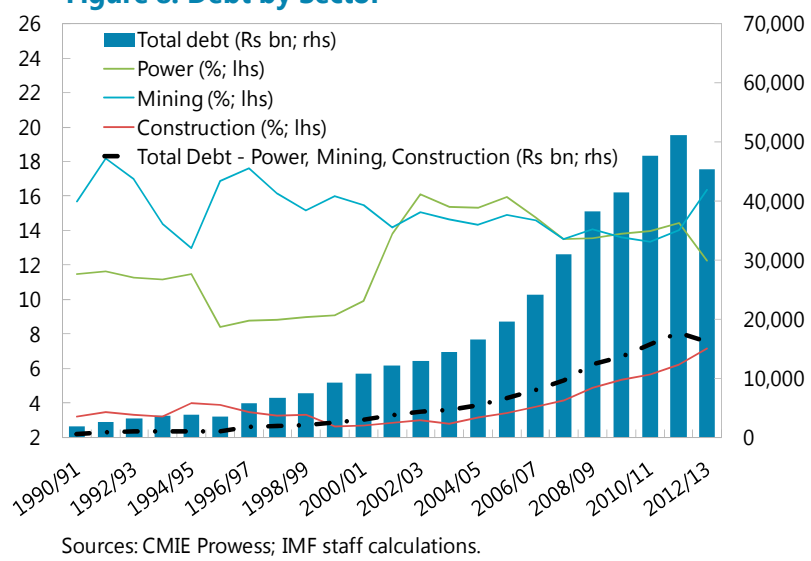

Figure 10. Interest Cover and Profitability

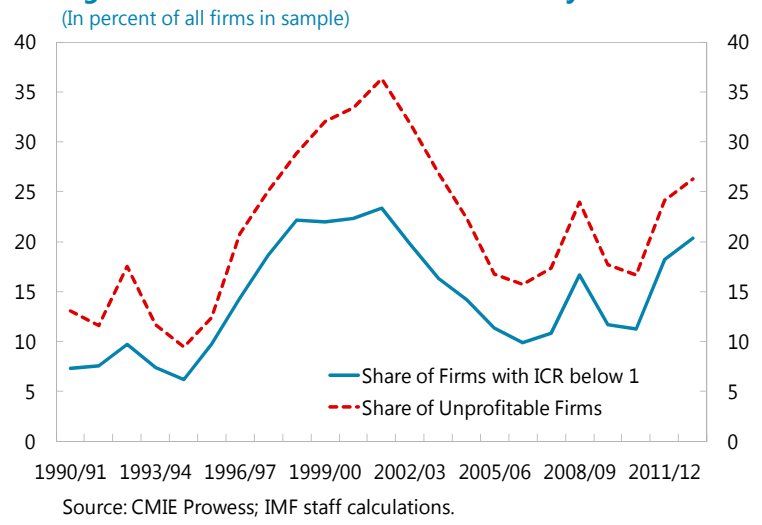

Figure 12. Share of Debt of Companies with ICR $<1$ (In percent)

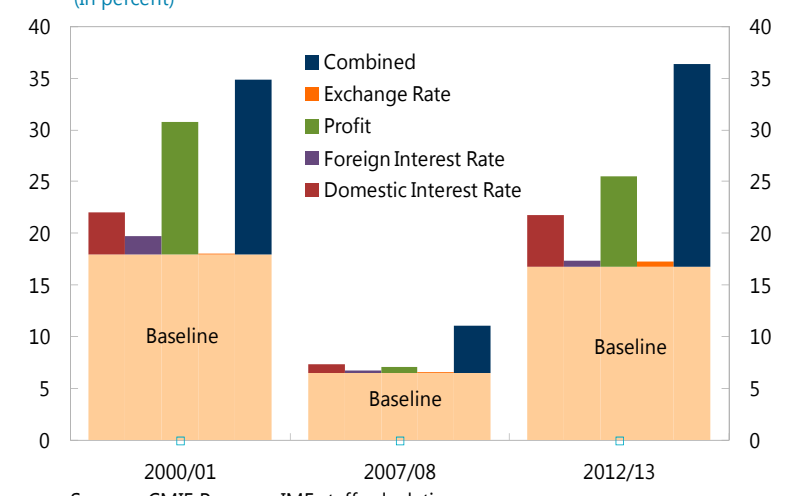

Sources: CMIE Prowess; IMF staff calculations.

\section{CInternational Monetary Fund. Not for Redistribution}


Figure 13. Share of Number of Companies with ICR $<1$

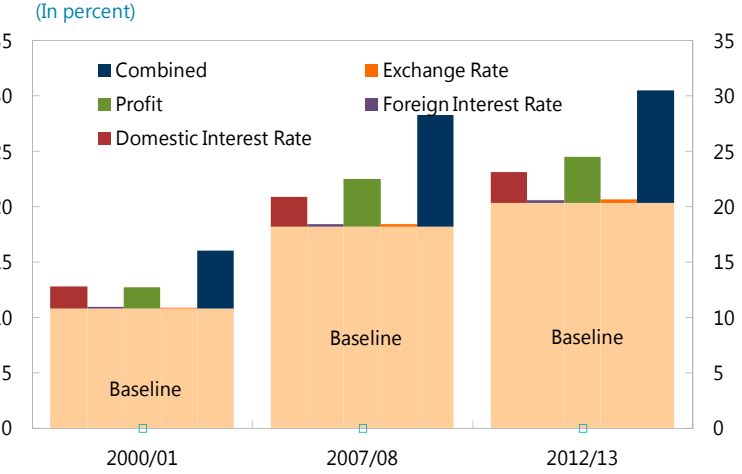

Sources: CMIE Prowess; IMF staff calculations.

Figure 15.Loan Impairments vs. Tier 1 Ratio, March 2013

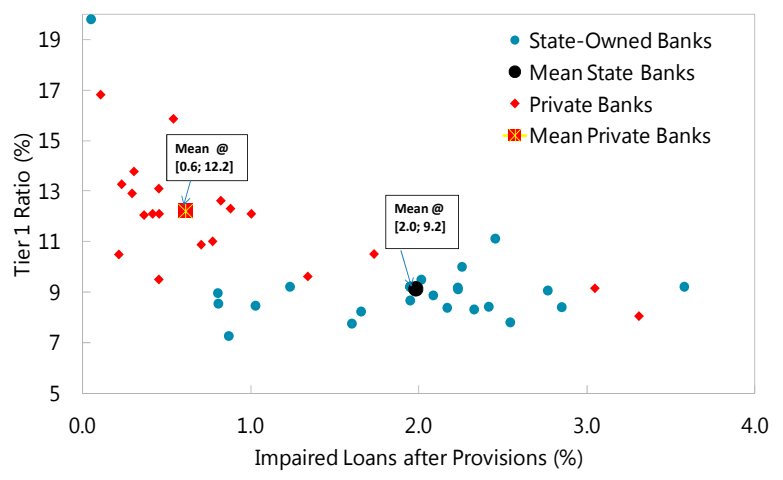

Sources: Bankscope; Reserve Bank of India; and IMF staff calculations.
Figure 14. Gross NPAs, Restructured Advances, and Slippages

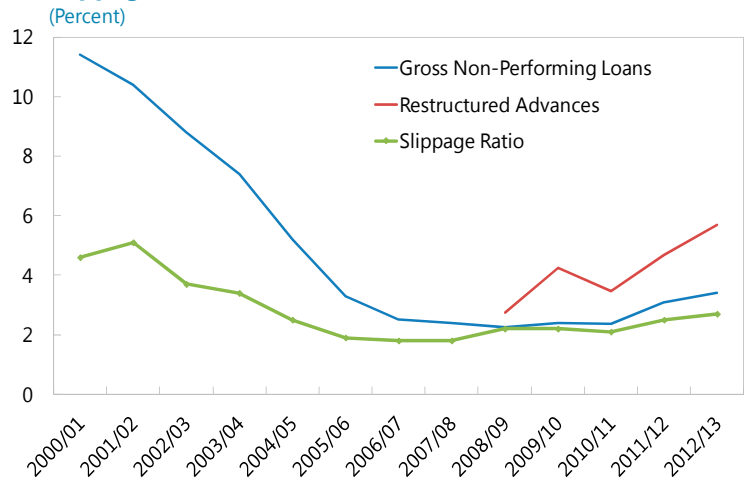

Figure 16. Loan Impairments vs. Tier 1 Ratio (post-shock) 1/

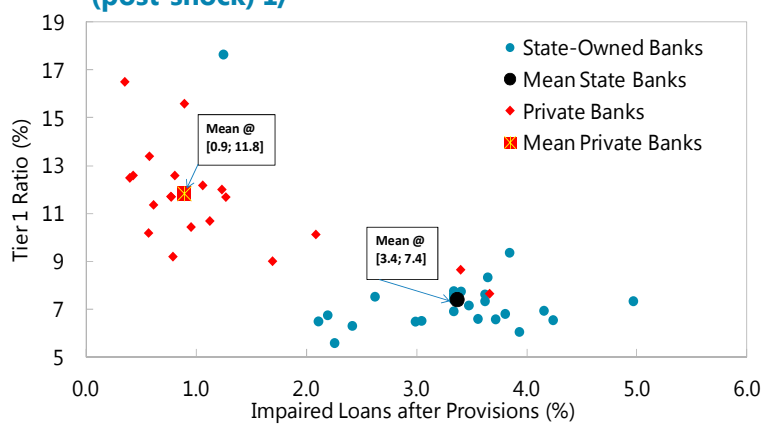

$1 /$ Shock $=45 \%$ of restructured advances become NPAs, \& all NPAs are provisioned at $\min .60 \%$

Sources: Bankscope; Reserve Bank of India; and IMF staff calculations. 


\section{Appendix: Tables}

\section{Table A1. Interest Cover, Profitability, Liquidity and Leverage for Major Indian Non-} Financial Corporates

Share of Debts held by Firms below/above Threshold Values

\begin{tabular}{lcccc} 
& ICR (<1) 1/ & $\begin{array}{r}\text { Profitability (<0) 2/ } \\
\text { (percent of total borrowing in sample) }\end{array}$ & Liquidity $(<\mathbf{0 . 5}) \mathbf{3}$ Leverage (>5) 4/ \\
\hline $1990 / 91$ & 2.6 & 4.5 & 0.5 & 4.9 \\
$1991 / 92$ & 3.6 & 4.1 & 0.5 & 0.5 \\
$1992 / 93$ & 4.1 & 5.3 & 0.7 & 3.8 \\
$1993 / 94$ & 2.7 & 3.4 & 0.7 & 2.2 \\
$1994 / 95$ & 3.2 & 3.9 & 0.3 & 0.8 \\
$1995 / 96$ & 5.4 & 5.7 & 0.2 & 9.6 \\
$1996 / 97$ & 5.5 & 7.5 & 0.9 & 20.7 \\
$1997 / 98$ & 11.1 & 13.7 & 1.2 & 37.2 \\
$1998 / 99$ & 22.5 & 26.1 & 2.5 & 43.4 \\
$1999 / 00$ & 22.4 & 29.3 & 13.5 & 42.2 \\
$2000 / 01$ & 18.0 & 29.8 & 15.6 & 43.9 \\
$2001 / 02$ & 21.5 & 29.2 & 13.4 & 43.5 \\
$2002 / 03$ & 15.7 & 25.2 & 14.6 & 42.1 \\
$2003 / 04$ & 11.4 & 17.4 & 13.5 & 28.5 \\
$2004 / 05$ & 8.4 & 10.4 & 11.2 & 12.2 \\
$2005 / 06$ & 8.7 & 9.3 & 9.2 & 7.9 \\
$2006 / 07$ & 6.6 & 8.5 & 10.0 & 8.4 \\
$2007 / 08$ & 6.5 & 11.1 & 13.1 & 10.0 \\
$2008 / 09$ & 9.4 & 14.9 & 13.5 & 24.9 \\
$2009 / 10$ & 5.6 & 9.0 & 15.1 & 11.7 \\
$2010 / 11$ & 6.2 & 13.9 & 11.0 & 15.7 \\
$2011 / 12$ & 14.8 & 21.3 & 15.8 & 26.7 \\
$2012 / 13$ & 16.8 & 26.5 & 17.7 & 29.5
\end{tabular}

Sources: CMIE Prowess database; IMF staff calculations.

Notes: Sample size about 2,800 firms (2013), declining to about 800 (1991).

Sample size varies with data availability.

Threshold values are shown in parentheses for column headers.

1/ EBITDA / Interest expenses.

2/ Profit after tax / Sales.

3/ 'Current Ratio' = Current assets / Current liabilities.

4/ Total debt / Market capitalization. 
Table A2. Results of Stress-Testing India's Non-Financial Corporate Sector

\begin{tabular}{|c|c|c|c|c|c|c|c|}
\hline & Baseline & $\begin{array}{c}\text { Domestic } \\
\text { Interest Rate } \\
\text { Shock } \\
+250 \text { bps }\end{array}$ & $\begin{array}{l}\text { Foreign Interest } \\
\text { Rate Shock } \\
\text { +400 bps }\end{array}$ & $\begin{array}{c}\text { Profit } \\
\text { Shock } \\
-25 \text { percent }\end{array}$ & $\begin{array}{l}\text { FX Shock } \\
+29 \text { percent }\end{array}$ & Combined & $\begin{array}{c}\text { Sample } \\
\text { Size }\end{array}$ \\
\hline & \multicolumn{6}{|c|}{ Share of debt of companies with ICR $<1$ in total corporate sector debt (in percent) } & \\
\hline March 1991 & 2.58 & 4.37 & 2.58 & 4.85 & 2.58 & 11.25 & 779 \\
\hline March 1992 & 3.62 & 5.56 & 3.62 & 5.41 & 3.84 & 12.29 & 883 \\
\hline March 1993 & 4.08 & 5.74 & 4.49 & 5.97 & 4.08 & 11.22 & 1,043 \\
\hline March 1994 & 2.72 & 4.61 & 2.72 & 3.72 & 2.72 & 7.75 & 1,328 \\
\hline March 1995 & 3.18 & 5.56 & 3.18 & 4.35 & 3.18 & 10.04 & 1,448 \\
\hline March 1996 & 5.44 & 6.87 & 5.44 & 7.08 & 5.44 & 12.69 & 1,066 \\
\hline March 1997 & 5.53 & 6.87 & 5.53 & 8.12 & 5.53 & 15.47 & 1,728 \\
\hline March 1998 & 11.12 & 13.87 & 11.25 & 15.98 & 11.28 & 32.89 & 1,741 \\
\hline March 1999 & 22.51 & 26.62 & 22.53 & 27.78 & 22.73 & 36.69 & 1,826 \\
\hline March 2000 & 22.37 & 26.28 & 22.55 & 28.62 & 22.55 & 34.59 & 2,168 \\
\hline March 2001 & 17.96 & 22.01 & 19.73 & 30.74 & 18.04 & 34.81 & 2,199 \\
\hline March 2002 & 21.48 & 27.11 & 21.48 & 25.77 & 21.48 & 33.52 & 2,261 \\
\hline March 2003 & 15.70 & 17.55 & 15.70 & 17.64 & 15.70 & 29.27 & 2,297 \\
\hline March 2004 & 11.44 & 13.76 & 11.44 & 13.39 & 11.44 & 18.30 & 2,308 \\
\hline March 2005 & 8.43 & 12.03 & 8.43 & 9.71 & 8.43 & 14.32 & 2,350 \\
\hline March 2006 & 8.66 & 9.84 & 8.74 & 9.19 & 8.74 & 11.32 & 2,446 \\
\hline March 2007 & 6.64 & 7.66 & 6.64 & 7.39 & 6.64 & 9.03 & 2,478 \\
\hline March 2008 & 6.49 & 7.40 & 6.76 & 7.11 & 6.54 & 11.09 & 2,534 \\
\hline March 2009 & 9.38 & 13.30 & 9.74 & 12.01 & 9.70 & 18.33 & 2,580 \\
\hline March 2010 & 5.57 & 6.39 & 5.58 & 7.62 & 5.57 & 15.10 & 2,601 \\
\hline March 2011 & 6.20 & 8.89 & 6.22 & 7.87 & 6.22 & 18.29 & 2,623 \\
\hline March 2012 & 14.78 & 16.80 & 15.36 & 18.83 & 15.34 & 29.27 & 2,700 \\
\hline March 2013 & 16.80 & 21.80 & 17.37 & 25.53 & 17.27 & 36.36 & 2,764 \\
\hline
\end{tabular}

Sources: CMIE Prowess database; IMF staff calculations. 
Table A3. Regression Results: Slippage Ratio on Lagged Dependent and 11 Different Explanatory Variables 1/ 2/

\begin{tabular}{|c|c|c|c|}
\hline \multirow{4}{*}{ Variable } & \multicolumn{2}{|c|}{ Coefficients } & \multirow[t]{4}{*}{ R-Squared } \\
\hline & Lagged & Other & \\
\hline & Endogenous & Explanatory & \\
\hline & Variable & Variable & \\
\hline \multirow[t]{2}{*}{ ICR } & 0.31 & 0.16 & $82.9 \%$ \\
\hline & $(1.5)$ & $(2.2)^{*}$ & \\
\hline \multirow[t]{2}{*}{ Profitability } & 0.34 & 0.09 & $85.1 \%$ \\
\hline & $(2.1)^{*}$ & $(2.8)^{* *}$ & \\
\hline \multirow[t]{2}{*}{ Liquidity } & 0.71 & 0.08 & $78.3 \%$ \\
\hline & $(4.5)^{* *}$ & (1.5) & \\
\hline \multirow[t]{2}{*}{ Leverage } & 0.33 & 0.05 & $79.6 \%$ \\
\hline & (1.3) & $(2.1)^{*}$ & \\
\hline \multirow[t]{2}{*}{ Equity Returns } & 0.69 & -0.01 & $82.6 \%$ \\
\hline & $(4.8)^{* *}$ & $(-2.7)^{* *}$ & \\
\hline \multirow[t]{2}{*}{ GDP Growth Nominal } & 0.56 & -0.08 & $77.5 \%$ \\
\hline & $(3.4)^{* *}$ & $(-1.9)^{*}$ & \\
\hline \multirow[t]{2}{*}{ GDP Growth Real } & 0.68 & -0.08 & $77.9 \%$ \\
\hline & $(3.8)^{* *}$ & $(-2.9)^{* *}$ & \\
\hline \multirow[t]{2}{*}{ CPI Inflation } & 0.86 & 0.06 & $76.9 \%$ \\
\hline & $(4.1)^{* *}$ & $(1.8)^{*}$ & \\
\hline \multirow[t]{2}{*}{ GDP Inflation } & 0.81 & 0.04 & $74.8 \%$ \\
\hline & $(3.9)^{* *}$ & $(0.6)$ & \\
\hline \multirow[t]{2}{*}{ Short Rate } & 0.91 & 0.27 & $85.8 \%$ \\
\hline & $(5.0)^{* *}$ & $(3.1)^{* *}$ & \\
\hline \multirow[t]{2}{*}{ Long Rate } & 0.79 & 0.16 & $77.8 \%$ \\
\hline & $(4.3)^{* *}$ & (1.0) & \\
\hline \multirow[t]{2}{*}{ Real Short Rate (CPI Index) } & 0.79 & -0.01 & $74.6 \%$ \\
\hline & $(2.9)^{* *}$ & $(-0.4)$ & \\
\hline \multirow[t]{2}{*}{ Real Short Rate (GDP Defl.) } & 0.66 & -0.01 & $83.2 \%$ \\
\hline & $(4.7)^{* *}$ & $(-2.8)^{* *}$ & \\
\hline \multirow[t]{2}{*}{ Real Long Rate (CPI Index) } & 0.50 & 0.03 & $76.1 \%$ \\
\hline & $(2.0)^{*}$ & $(1.6)$ & \\
\hline \multirow[t]{2}{*}{ Real Long Rate (GDP Defl.) } & 0.68 & -0.01 & $83.1 \%$ \\
\hline & $(4.8)^{* *}$ & $(-2.8)^{* *}$ & \\
\hline
\end{tabular}

Source: IMF staff calculations.

$1 / t$-values are shown underneath each coefficient.

2/ Heteroscedasticity and autocorrelation-corrected standard errors used. 


\section{REFERENCES}

Anand, R. and V. Tulin, 2014, “Disentangling India's Investment Slowdown,” IMF Working Paper 14/47 (Washington: International Monetary Fund).

Credit Suisse, 2013, "India Financial Sector: House of Debt-Revisited," August 13.

Economic Times, 2013, "United Bank of India faces Auditing, Corporate Governance Probes," March.

Financial Express, 2012, "Around 65\% of India Inc's forex exposure unhedged: RBI," October 17.

International Monetary Fund, 2014, India: 2014 Article IV Consultation, IMF Country Report No. 14/57 (Washington: International Monetary Fund).

Jones, M.T. and M. Karasulu, 2006, "The Korean Crisis: What Did We Know and When Did We Know It? What Stress Tests of the Corporate Sector Reveal," IMF Working Paper 06/114 (Washington: International Monetary Fund).

Lindner, P., 2014, "India's Corporate Sector: Health and Vulnerabilities," in India: Selected Issues, IMF Country Report No. 14/58 (Washington: International Monetary Fund).

Medina, L., 2012, "Spring Forward or Fall Back? The Post-Crisis Recovery of Firms," IMF Working Paper 12/292 (Washington: International Monetary Fund).

Moody's, 2004, " MOODY'S KMVTM RISKCALCTM V3.1 UNITED STATES," June 1. Available at: http://www.moodysanalytics.com/ /media/Insight/QuantitativeResearch/Default-and-Recovery/04-01-06-RiskCalc-v3-1-US.ashx.

Morgan Stanley, 2012, “How Do Asian Banks' Loss-Absorption Cushions Stack Up? (Part 2), ' Investment Grade Credit, Asian Bank Compass, August 28.

Oura, H., 2008, "Financial Development and Growth in India: A Growing Tiger in a Cage?" IMF Working Paper 08/79 (Washington: International Monetary Fund).

Oura, H. and P. Topalova, 2009, "India's Corporate Sector: Coping with the Global Financial Tsunami," in India: Selected Issues, IMF Country Report No. 09/186 (Washington: International Monetary Fund).

Reserve Bank of India, 2013, "Real Interest Rate Impact on Investment and Growth - What the Empirical Evidence for India Suggests," Intra-Departmental Study, August 8.

Standard \& Poor's, 2014, "India Banking Outlook 2014: Little Respite In Sight," RatingsDirect, February 10.

Tokuoka, K., 2012, "Does the Business Environment Affect Corporate Investment in India?" IMF Working Paper 12/70 (Washington: International Monetary Fund). 